\title{
Montroseite, a
}

New Vanadium Oxide from

the Colorado Plateaus

By Alice D. Weeks, Evelyn A. Cisney, and A. M. Sherwood $/ 888-$

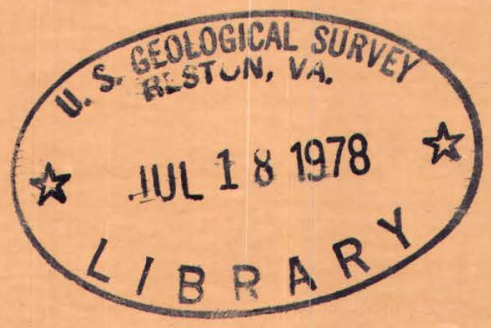

\section{Trace Elements Investigations Report 335}

UNITED STATES DEPARTMENT OF THE INTERIOR US GEOLOGICAL SURVEY 
This document consists of 14 pages. Series A.

UNITED STATES DEPARTMENT OF THE INTERIOR

U.S. GEOLOGICAL SURVEY

MONTROSEITE, A NEW VANADIUM OXIDE FROM THE COLORADO PLATEAUS*

By

Alice D. Weeks, Evelyn A. Cisney, and Alexander M. Sherwood

June 1953

Trace Elements Investigations Report 335

This preliminary report is distributed without editorial and technical review for conformity with official standards and nomenclature. It is not for public inspection or quotation. 
USGS - TEI -335

GEOLOGY AND MINERALOGY

Distribution (Series A)

No. of copies

American Cyanamid Company, Winchester ................ 1

Argonne National Laboratory ......................... I

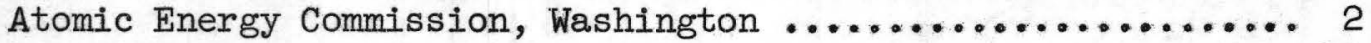

Battelle Memorial Institute, Columbus ................... I

Carbide and Carbon Chemicals Company, Y-12 Area ........... I

Division of Raw Materials, Butte ....................... I

Division of Raw Materials, Denver ..................... I

Division of Raw Materials, Grants ..................... 1

Division of Raw Materials, Hot Springs ................. I

Division of Raw Materials, New York ................... 6

Division of Raw Materials, Richfield .................... I

Division of Raw Materials, Salt Lake City ................ I

Division of Raw Materials, Washington ................. 3

Dow Chemical Company, Pittsburg ....................... I

Exploration Division, Grand Junction Operations Office ...... 6

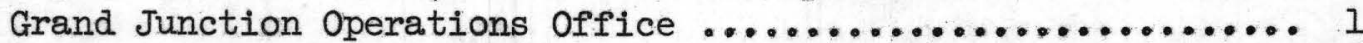

Technical Information Service, Oak Ridge ................ 6

Tennessee Valley Authority, Wilson Dam .................. 1

U. S. Geological Survey:

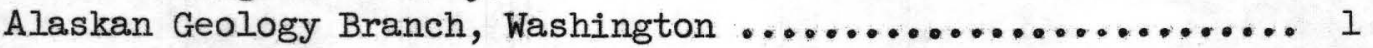

Fuels Branch, Washington ............................ 1

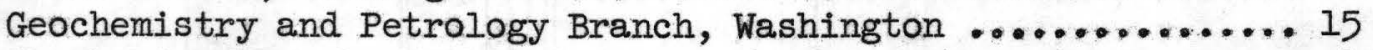

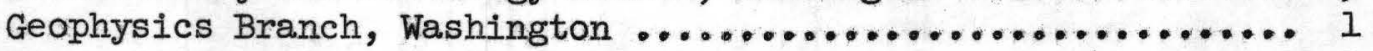

Mineral Deposits Branch, Washington .................. 1

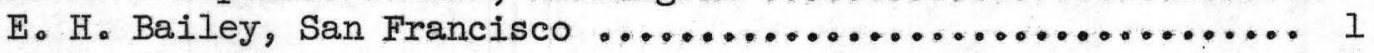

J. R. Cooper, Denver ............................... I

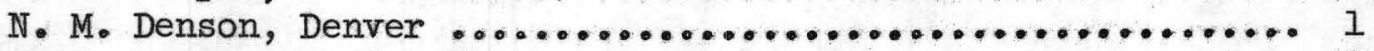

C. E. Dutton, Madison ............................... 1

R. P. Fischer, Grand Junction ....................... 2

L. S. Gardner, Albuquerque ......................... I

C. B. Hunt, Plant City ........................... 1

M. R. Klepper, Washington ........................ I

A. H. Koschmann, Denver .......................... 1

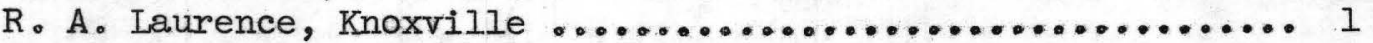

D. M. Lemmon, Washington ........................... 1

J. D. Love, Laramie . ................................ 1

L. R. Page, Denver ............................... 1

R. J. Roberts, Salt Lake City ....................... I

Q. D. Singewald, Beltsville ....................... 1

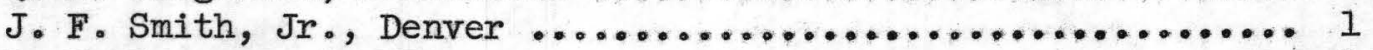

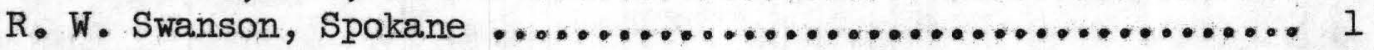

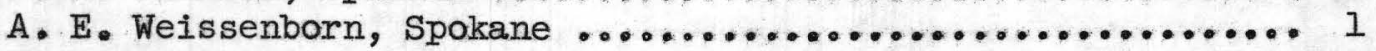

W. P. Williams, Joplin .......................... I

TEPCO, Washington:

Resource Compilation Section ........................ 2

Reports Processing Section .......................... 2

(Including master) 
CONTENTS

Page

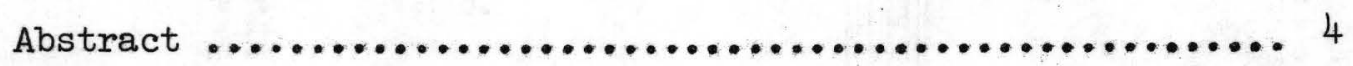

Introduction and acknowledgments $\ldots \ldots \ldots \ldots \ldots \ldots \ldots \ldots . . .4$

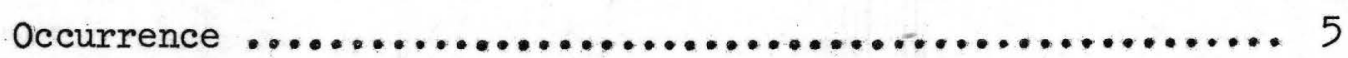

Physical properties $\ldots \ldots \ldots \ldots \ldots \ldots \ldots \ldots \ldots \ldots \ldots \ldots \ldots \ldots \ldots$

X-ray diffraction data $\ldots \ldots \ldots \ldots \ldots \ldots \ldots \ldots \ldots \ldots \ldots . \ldots$

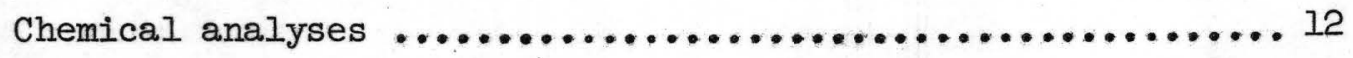

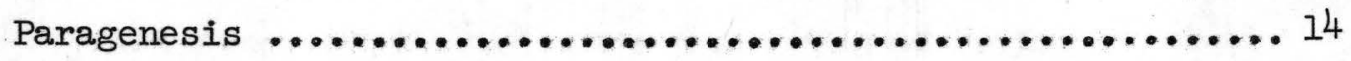

References ........................................ 14

ILLUSTRATIONS

Page

Figure 1. Index map of localities of montroseite ........6 6

2. Crystal drawing of montroseite ............... 10

TABLES

Page

Table 1. Angle table of montroseite ................... 9

2. X-ray diffraction powder pattern of montroseite ... II

3. Chemical analyses of montroseite ............. 13 
MONTROSEITE, A NEW VANADIUM OXIDE FROM THE COLORADO PIATEAUS

by

Alice D. Weeks, Evelyn A. Cisney, and Alexander M. Sherwood

\section{ABSTRACT}

Montroseite, a new vanadium mineral named from Montrose County, Colorado, has been found in four mines in western Colorado and in two mines in eastern Utah. It is black, opaque, submetallic, and occurs in microscopic bladed crystals of the orthorhombic dipyramidal class. The axial ratio is $a: b: c=0.509: 1: 0.310$, the common forms are $b\{010\}, m\{110\}, p\{121\}$, and a large vicinal form is approximately $\{0,10,1\}$. The observed specific gravity is 4.0 and the calculated specific gravity is 4.15 . The composition is essentially $\mathrm{VO}(\mathrm{OH})$, with some iron commonly substituted for vanadium. Partial oxidation to $\mathrm{VO}_{2}$ has taken place. Chemical analyses and X-ray diffraction data are given. Single crystal study indicated that the space group symmetry is $\mathrm{Pbnm}\left(\mathrm{D}_{2 \mathrm{~h}}{ }^{16}\right)$.

\section{INTRODUCTION AND ACKNOWLEDGMENTS}

Montroseite was first collected by L. R. Stieff, T. W. Stern, and M. N. Girhard of the U. S. Geological Survey during the summer of 1949 at the Bitter Creek mine, Montrose County, Colo., and studied by the writers in 1950. More montroseite was collected by A. D. Weeks from the Jo Dandy mine, Montrose County, and the Matchless mine, Mesa County, Colo., in 1950; from the Bitter Creek and the Whitney mines, Montrose County, Colo, in 1951, and from the Juniper mine, Grand County, Utah, in 1952. It was collected from the Rex No. 2 mine at Temple Mountain, Emery County, Utah, in 1952 by A. Rosenzweig of the Atomic Energy Commission. 
The mineral was named, after preliminary morphologic and X-ray study, and chemical analysis showed it to be different from any known vanadium mineral (Weeks, Cisney, and Sherwood, 1950). It was not fully described at that time because of the problem of a satisfactory chemical formula. The small unit cell determined by X-ray study indicated a simpler formula than was obtained from the chemical analysis.

Thanks are extended to L. R. Stieff, T. W. Stern, and M. N. Girhard who collected the first sample; H. T. Evans and Stanley Block of the Geological Survey who determined the crystal structure and the correct chemical formula; also George Switzer of the U. S. National Museum who furnished material for comparison with the new mineral.

\section{OCCURRENCE}

Four of the mines in which montroseite has been recognized are located in the Uravan mineral belt (Fischer and Hilpert, 1952) in western Colorado. The fifth locality, the Juniper mine, near Thompsons, Utah, is along a possible northwest extension of the Uravan belt. These five mines are in the Salt Wash sandstone member of the Morrison formation (Late Jurassic). The sixth locality is the Rex No. 2 mine in Shinarump conglomerate (Triassic) at Temple Mountain on the southeast side of the San Rafael swell in Utah. (See fig. 1.)

Montroseite occurs in black, relatively unoxidized vanadium-uranium ore, and is more abundant at the Bitter Creek and the Whitney mines where the ore is predominantly blacker than at the Jo Dandy mine where the ore is generally oxidized and consists of minerals such as carnotite, hewettite, and hummerite. A small amount of pitchblende found at the Juniper and the Rex No. 2 mines is further indication of the relatively unoxidized environment of montroseite. 


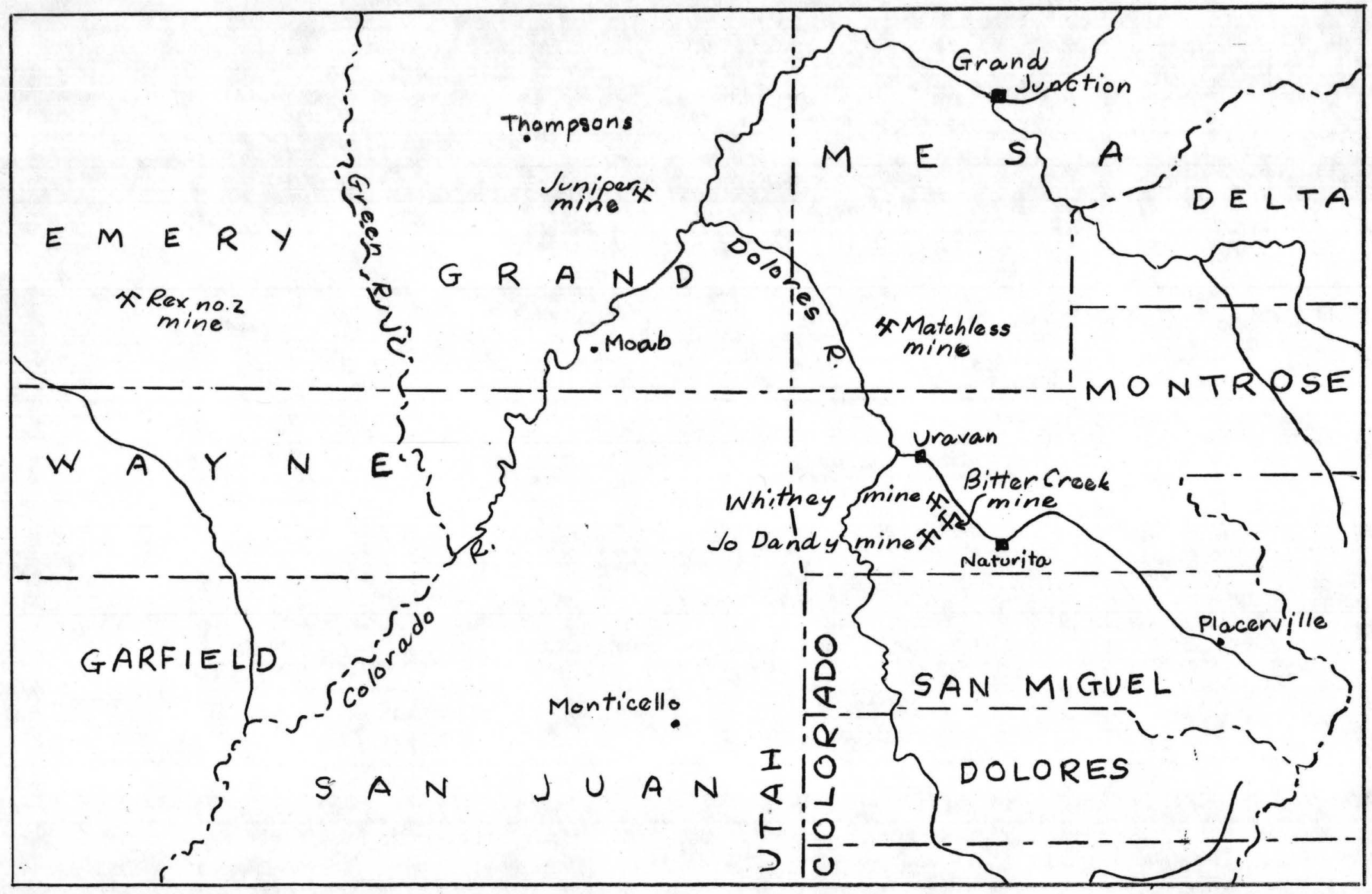

a

Figure 1.--Index map of localities of montroseite 
At the Bitter Creek and. Whitney mines montroseite is the chief vanadium ore mineral in the blackest ore but is less abundant than corvusite in the greenish-black or blue-black ore. At the Matchless mine a small amount of montroseite was found in a band of corvusite ore with thin seam fillings of hewettite. The montroseite is in microscopic crystals interstitial to the quartz grains of the ore-bearing sandstone. The occurrence at the Jo Dandy mine may represent a further development of the situation at the Matchless mine; at Jo Dandy there is a very small amount of montroseite in sma.11 dark patches of corvusite ore. At the Juniper mine a specimen of mineralized. fossil bone was found to have microscopic tubelike fillings of montroseite in brown apatite.

A few milligrams of nearly pure montroseite from the Rex No. 2 mine were sent to the writers for identification by A. Rosenzweig of the Atomic Energy Commission. It consisted of cleavage fragments and aggregates of grains larger than those in other samples, and was the only specimen suitable for measurement of specific gravity on a Berman balance.

\section{PHYSICAL PROPERTIES}

Montroseite is black, opaque with submetallic luster, and black streak. It forms microscopic crystals randomly oriented in massive ore, filling interstices between quartz sand grains, or filling small tubelike openings in fossil bone. Only the samples from the Bitter Creek mine contained single crystals large enough for goniometric and X-ray single crystal study. These bladed crystals of the orthorhombic dipyramidal class are commonly attached at one end and terminated with dome and pyramid faces on the other end. The crystals have good cleavage parallel to the length of the blade, $\{100\}$, and are brittle. Superficially the appearance of montroseite resembles that of 
melanovanadite in that both form elongated black crystals, but montroseite is orthorhombic and opaque whereas melanovanadite is triclinic and strongly pleochroic in black and red. From the unit cell dimensions and chemical formula, the specific gravity of montroseite is calculated to be 4.15 . The only specimen suitable for measurement of specific gravity, from the Rex No. 2 mine, Emery County, Utah, gave 4.0. Montroseite can be separated or concentrated from the minerals with which it occurs by the use of methylene iodide and by the Frantz isodynamic separator because it is heavy and more magnetic than the associated minerals.

Goniometric measurements made on several crystals were inaccurate because of poor reflections, small faces, and multiple growth of crystals. They only served to determine the forms present, and the angle table (table 1 ) has been computed from the unit cell lengths found by X-ray diffraction. The bladed crystals (fig. 2) consist chiefly of the brachypinacoid and a steep brachydome, both with rough surfaces. The $\rho$ angle of $p\{121\}$ could be determined better by finding a small circle including some reflection from the four small faces than by measuring each individually, and this angle was between $40^{\circ} 31^{\prime}$ and $41^{\circ}$, in good agreement with the calculated angle.

\section{X-RAY DIFFRACTION DATA}

The X-ray powder pattern of montroseite distinguishes it from the other black vanadium minerals: melanovanadite, corvusite, and vanoxite (considered. a doubtful species by the writers). Morphologic study indicated that montroseite belongs to the orthorhombic system and this was borne out by $\mathrm{X}$-ray study. Rotation and Weissenberg photographs taken around the $\underline{c}$ and a axes were poor and did not give sharp reflections, but the extinctions indicated the space group to be Pbnm $\left(\mathrm{D}_{2 \mathrm{~h}}{ }^{16}\right)$. From approximate measurements on the Weissenberg photographs the powder pattern was indexed (table 2) and 
9

Table 1.--Angle table of montroseite

Orthorhombic; dipyramidal, 2/m 2/m 2/m

$a: b: c=0.509: 1: 0.310$

$q_{1}: r_{1}: p_{1}=0.509: 1.645: 1$ $p_{0}: q_{0}: r_{0}=0.608: 0.310: 1$

$r_{2}: p_{2}: q_{2}=3.226: 1.961: 1$

\begin{tabular}{lrlllll}
\hline Forms & $\varphi$ & $\rho=c$ & $\varphi_{1}$ & $\rho_{1}=\mathrm{A}$ & $\rho_{2}$ & $\rho_{2}=\mathrm{B}$ \\
\hline b 010 & $0^{\circ} 00^{\prime}$ & $90^{\circ} 00^{\prime}$ & $90^{\circ} 00^{\prime}$ & $90^{\circ} 00^{\prime}$ & - & $0^{\circ} 00^{\prime}$ \\
m 110 & $62^{\circ} 59^{\prime}$ & $90^{\circ} 00^{\prime}$ & $90^{\circ} 00^{\prime}$ & $27^{\circ} 01^{\prime}$ & $0^{\circ} 00^{\prime}$ & $62^{\circ} 59^{\prime}$ \\
p 121 & $44^{\circ} 26^{\prime}$ & $40^{\circ} 58^{\prime}$ & $31^{\circ} 48^{\prime}$ & $62^{\circ} 41^{\prime}$ & $58^{\circ} 42^{\prime}$ & $62^{\circ} 05^{\prime}$
\end{tabular}

uncertain form

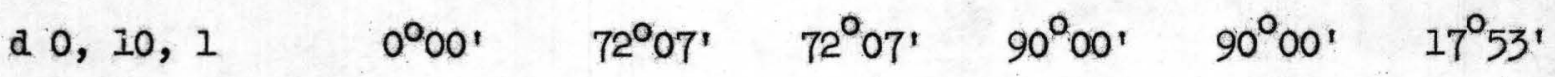




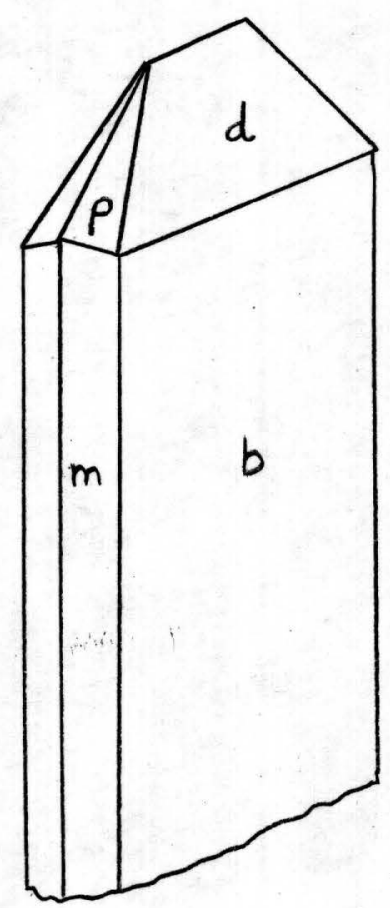

Figure 2.--Crystal drawing of montroseite 
Table 2.--X-ray diffraction powder pattern of montroseite. $\mathrm{D}$-spacings and relative intensity (CuKo radiation).

Spacings in A units

\begin{tabular}{|c|c|c|c|}
\hline hkl & Calculated & Measured & Intensity \\
\hline 020 & 4.74 & 4.75 & VF \\
\hline 110 & 4.30 & 4.31 & $\mathrm{~s}$ \\
\hline 120 & 3.38 & 3.38 & M \\
\hline 130 & 2.643 & 2.644 & $\mathrm{~s}$ \\
\hline 101 & 2.507 & & \\
\hline 021 & 2.495 & 2.495 & M \\
\hline 111 & 2.424 & 2.423 & W \\
\hline 121 & 2.216 & 2.217 & M \\
\hline 220 & 2.149 & 2.151 & F \\
\hline 131 & 1.963 & 1.965 & W \\
\hline 230 & 1.917 & 1.918 & W \\
\hline 041 & 1.843 & 1.841 & $\mathrm{Fb}$ \\
\hline 221 & 1.734 & 1.731 & W \\
\hline 241 & 1.690 & 1.689 & W \\
\hline 321 & 1.605 & 1.605 & w \\
\hline 151 & 1.512 & 1.512 & M \\
\hline 250 & 1.491 & 1.490 & W \\
\hline 002 & 1.467 & 1.467 & W \\
\hline 061 & 1.391 & 1.391 & w \\
\hline 112 & 1.388 & & \\
\hline 170 & 1.304 & 1.302 & F \\
\hline 132 & 1.283 & 1.282 & F \\
\hline
\end{tabular}


the unit cell lengths were recalculated from measurements on the powder pattern. The unit cell lengths, $a_{0}=4.82, b_{0}=9.48$, and $c_{0}=2.93$, obtained in this way agree more closely with the diffuse lattices than the sharp lattice of Evans and Block (1953). This is probably because the sample used for the powder pattern was considerably altered to $\mathrm{VO}_{2}$, whereas the single crystals contained a well-crystallized portion of the original $\mathrm{VO}(\mathrm{OH})$.

\section{CHEMICAL ANALYSES}

Montroseite presented a problem in chemical analysis because the vanadium is commonly in two valences and some iron substitutes for vanadium. A portion of the sample was digested in $\mathrm{H}_{2} \mathrm{SO}_{4}$, in the absence of air and was titrated with $\mathrm{K}_{2} \mathrm{Cr}_{2} \mathrm{O}_{7}$. In this titration $\mathrm{V}_{2} \mathrm{O}_{3}$ is oxidized to $\mathrm{V}_{2} \mathrm{O}_{4}$, and $\mathrm{FeO}$ to $\mathrm{Fe}_{2} \mathrm{O}_{3}$. A second portion was digested in the same manner and was titrated with $\mathrm{KMnO}_{4}$. In this titration $\mathrm{V}_{2} \mathrm{O}_{3}$ is oxidized to $\mathrm{V}_{2} \mathrm{O}_{5}, \mathrm{~V}_{2} \mathrm{O}_{4}$; to $\mathrm{V}_{2} \mathrm{O}_{5}$, and $\mathrm{FeO}$ to $\mathrm{Fe}_{2} \mathrm{O}_{3}$. Total $\mathrm{V}$ and $\mathrm{Fe}$ were determined on separate portions. The analyses (table 3) were computed from these determinations: total $\mathrm{FeO}$ and $\mathrm{V}_{2} \mathrm{O}_{3}$, total reducing ability of the mineral, total $\mathrm{V}$, and total $\mathrm{Fe}$.

The chemical analyses may be interpreted in the light of information obtained by X-ray structure study (Evans and Block, 1953). Ideally the original composition of montroseite was Vo(OH), but the substitution of FeO requires an equivalent amount of $\mathrm{V}_{2} \mathrm{O}_{4}$. In the chemical analyses, the amount of $\mathrm{V}_{2} \mathrm{O}_{4}$ in excess of that required to balance the FeO represents the oxidation of the original mineral. The amount of water decreases as $\mathrm{VO}(\mathrm{OH})$ alters to $\mathrm{VO}_{2}$. Calculation of the analysis (table 3 , column 3) of the sample from the Matchless mine, Colo., indicates about 35 percent of 
Table 3.--Chemical analyses of montroseite (in percent) Analyst: A. M. Sherwood, U. S. Geological Survey

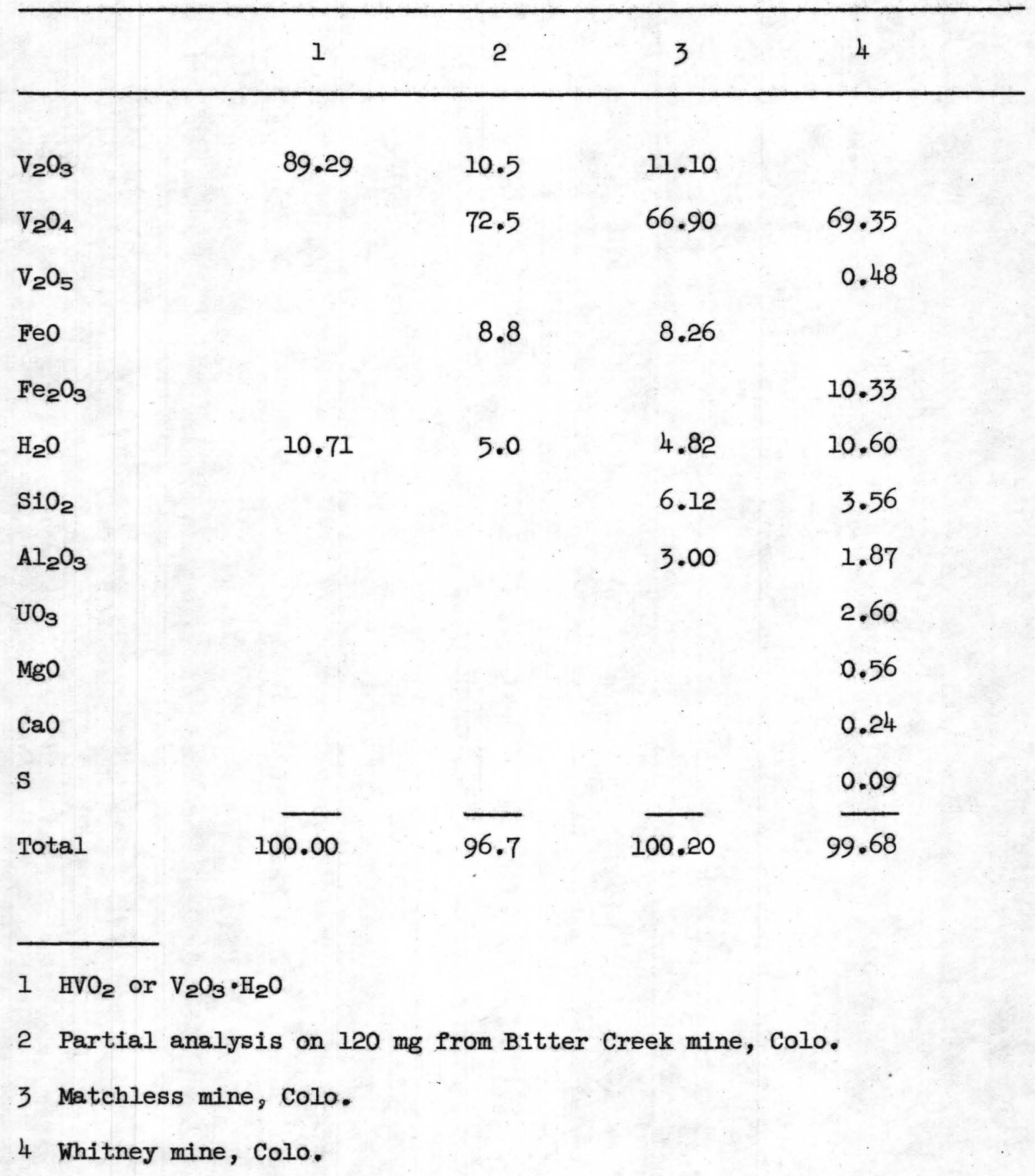


$\left[\left(\mathrm{Fe}^{+2} \cdot \mathrm{V}^{+4}\right), \mathrm{V}^{+3}\right] \mathrm{O}(\mathrm{OH})$ and about 65 percent of $\mathrm{vO}_{2}$.

None of the montroseite samples could be separated completely from the associated minerals chiefly because montroseite occurs in such fine-grained mixtures. The sample (table 3, column 2) from the Bitter Creek mine (120 mg) was a loose aggregate of crystals and probably the purest of the three analyzed samples. The sample from the Matchless mine (table 3, column 3) contained microscopic grains of montroseite between quartz grains and is only about 90 percent pure. The sample (about $12 \mathrm{~g}$ ) from the Whitney mine (table 3, column 4) is not more than 85 percent pure and contains clay, possibly corvusite and a new black uranium mineral, and a little pyrite.

\section{PARAGENESIS}

Montroseite is the least oxidized vanadium mineral thus far found in the Colorado Plateaus uranium-vanedium ores and it is thought to be a primary mineral. It occurs with or in the same environment as pitchblende and a new black uranium mineral not yet described, as well as pyrite, galena, and other sulfides. In the zone of oxidation it is altered to corvusite, melanovanadite, and the quinquivalent vanadium minerals: hewettite, pascoite, and hummerite.

\section{REFERENCES}

Evans, H. T., and Block, S., 1953, Montroseite, a new vanadium analog of the diaspore group of minerals: U. S. Geol. Survey Trace Elements Inv. Rept. (in preparation).

Fischer, R. P., and Hilpert, L. S., 1952, Geology of the Uravan mineral belt: U. S. Geol. Survey Bull. 988-A, 13 pp.

Weeks, A. D., Cisney, E. A., and Sherwood, A. M., 1950, Hummerite and montroseite, two new vanadium minerals from Montrose County, Colorado: Geol. Soc. America Bull., vol. 61, p. 1513, (abstract). 